\title{
Teaching English Vocabulary through TPR Method in Virtual Classroom: Students' Perception at Fifth Grade Thai Students
}

\author{
Maulidiah Prihati Ningrum \\ Student of English Education Department, University of Muhammadiyah Gresik, Indonesia \\ Email : maulidiah_170403@umg.ac.id \\ Ulfatul Ma'rifah \\ Lecturer of English Education Department, University of Muhammadiyah Gresik, Indonesia \\ Email : Ulfahmarifah@umg.ac.id
}

\begin{abstract}
This study aims to investigate the students' perception of teaching English vocabulary toward the Total Physical Response (TPR) method in virtual classrooms. This research used a survey design and Focus Group Discussion. The students have taught the English vocabulary toward the TPR method virtually for about 4 months in the odd semester 2020-2021. The objects of this research were fifth-grade students of Ban Wangmuang School, Loei Thailand. The result showed that the students positively perceived the use of the TPR method in English vocabulary in a virtual class. The Total Physical Response (TPR) method makes the students feel more enjoyable, happy, and active with the various activities which can increase the students' participation during the virtual class. It could help the students to understand and remember new vocabulary easier.
\end{abstract}

Keywords: Teaching English Vocabulary, TPR Method, Virtual Classroom.

\section{Introduction}

In this new normal era, virtual classrooms could be future schools in the world. By using a virtual classroom, the teacher and students do not need to interact face to face in one room. A virtual classroom is not too different than a traditional classroom. In virtual class, the teacher and the students do the learning activities in front of a camera of the computer somewhere and they can interact with each other in the virtual class (Alhat, 2020). Therefore there are a lot of schools forced to implement the teaching process into virtual classrooms, including teaching English. Although in a virtual class, teaching English vocabulary should not be forgotten by the teachers in teaching English process, because it is very important in determining the student's ability in mastering the targeted language.

Vocabulary is the learning of fundamental language, whether the vocabulary is the first, the second, or the foreign language (Gayanti \& Satriani, 2020). Vocabulary is also the foundation that produces languages, which plays a fundamental role in communication; the most important component of many language classes is teaching vocabulary. Thus, vocabulary is a very important role in communication with each other and plays a significant role in language skills, such as listening, speaking, reading, and writing skills (Ho et al., 2018). In addition, vocabulary is central to foreign language learning at the basic level (Cameron, 2010). It means that learning vocabulary is very important as the basic need to get a new language.

However, many English learners have difficulties when learning vocabulary and faced many problems in vocabulary lessons. Some students think it is difficult to memorize English vocabulary because they not interested and rarely use that vocabulary in their daily life. Especially during virtual classes, the students lack motivation because they often just sit quietly and listen to the teacher's audios or watch some videos. Sometimes, there were some troubles from the signal and made the teachers cannot share a kind of media (video, YouTube, and etc.). One of the main disadvantages of learning virtually is that it requires a computer and a steady internet connection (Alhat, 2020).

Therefore, teachers should provide some techniques to make students be able to learn vocabulary is for their English language. The Total Physical Response (TPR) method is one of the ways in achieving vocabularies for the students. In this method, a physical movement is used in responding to what students hear from the teacher's instructions. According to (Ibrohim, A. T., \& Septianti, 2018) The Total Physical Response (TPR) is a method in teaching English developed by James T. Asher. By using this method the teacher requires gestures, actions, and sounds. Through Total Physical Response, it will motivate the students to have attention and participation to respond to the teachers' instructions in learning a foreign language. Afterward, the teacher can use the general items, for instance, rulers, pens, and other tools (Ho et al., 2018). The use of the TPR method makes the students 
become more enjoyable and easier to memorize the vocabulary taught, all students were actively involved in the teaching-learning process, and both students and teacher enjoy the teaching-learning process (Bahtiar, 2017).

Numerous researchers have investigated the use of the Total Physical Response (TPR) method in teaching English vocabulary for various students, especially for young students. (Shi, 2018) investigated the TPR teaching method of primary students in China. This study was used the experimental study and the researcher was concluded that the use of the TPR teaching method to teach students, learning atmosphere, and classroom activity participations are better than the traditional method. Therefore TPR teaching method can make students more attractive learning in the class so that they learn English through body movements without too much explicit pressure. (Gayanti \& Satriani, 2020) found the vocabulary improvement of Total Physical Response (TPR) in the eighth grade. The finding of the qualitative method was showed the result that students can improve their vocabularies well through TPR. Moreover, the TPR method is a suitable method to use by teachers in teaching English because the students can more understand what they learn from the method.

(Khakim \& Anwar, 2020) investigated the effectiveness of using the Total Physical Response (TPR) method in improving students' vocabulary mastery at Indonesian private Islamic junior high school. The researchers have used the quasi-experimental research design and concluded that the use of the Total Physical Response was effective to improve the students' vocabulary mastery of the Indonesian private Islamic junior high school students. Therefore the lack of students' vocabulary mastery can be solved by implementing the TPR method, but we did not know whether it is an interesting method for the students or not. Then (Ibrohim, A. T., \& Septianti, 2018) investigated the students' perception and identified the advantages of the Total Physical Response (TPR) technique that applied in teaching vocabulary. The result of the qualitative descriptive research method was showed that there is some improvement of the students' speaking ability and increasing vocabulary, Increase the student's participation in the class and with that method can give a fun learning atmosphere in the classroom.

In addition, (Widodo, 2005) has collected the advantages of the TPR method. First, this method makes the students enjoy and fun to learn in the classroom. Second, this method is very memorable because this method does assist students to recognize phrases or words. Third, it is good for young students who are required to be active in the classroom. Forth, this method can be used no matter how many students involved, as long as the teachers' prepared to take the lead, the students will follow the activities. Fifth, the physical actions get across the meaning effectively enable all the students to comprehend and apply the target language. Sixth, for the teacher, it is no need to have a lot of preparation or materials using the TPR. Seventh, it is a very effective method that can be used for both teenagers and young learners. The last, it needs the coordination of both the right and left hemispheres of the human brain. Based on the explanation above it concluded that the TPR method is one of the effective methods that can motivate students to be more active and interested to learn English vocabulary.

Mostly the previous studies, the researchers taught English vocabulary used the TPR method in offline classrooms, and the TPR method was successfully motivated and improved students' English skills, such as vocabulary (Shi, 2018; Eka, E., \& Setiawan, 2018; Ibrohim, A. T., \& Septianti, 2018; Fahrurrozi, 2017). In general, the results of those studies indicate that the use of the TPR method in the traditional classroom has successfully enhanced students' English vocabulary mastery. But, so far there has been no researcher that discusses and finds the result of the TPR method in virtual classes. Besides, the virtual classrooms could be the future schools of our world in this new normal era (Alhat, 2020). Therefore, in this study, the researchers are interested to investigate the students' perception toward teaching English vocabulary by applying the TPR method in a virtual class at fifth grade of Ban Wangmuang School at Erawan sub-district, Loei Thailand.

\section{Methodology}

This researcher was used in a survey design. In relation to this research, a survey design was chosen because the research will present the students' perception toward teaching English vocabulary through TPR (Total Physical Response) method in the virtual classroom. In addition, at the end of this study, the researchers build a conclusion based on the data gained.

This research was carried out in the Primary School at Ban Wangmuang School in Erawan sub-district, Loei Thailand. (McMillan, James H., 2001) states that a population is a set of elements, whether individual, object or even those match certain criteria and are intended to generalize the results of the study. In this research, the researchers will take the population from the primary students of the fifth grade of Ban Wangmuang school academic year 2020-2021 and students' perception. Based on (McMillan, James H., 2001) arguments, the sample can be selected from a larger group or person, which is identified as the population or it can simply refer to the 
subject from which data is collected even if the subject is not selected for the population. Therefore, the sample of this research was 39 students of the fifth grade of Ban Wangmuang School in the academic year 2020-2021.

\section{Instrument}

Data collection techniques used online survey and Focus Group Discussion (FGD) was administered for data collection. First, the survey with 10 statement items (table 1) was adapted from a previous study by (Ibrohim, A. T., \& Septianti, 2018) and the researchers modified some of the questionnaires to adjust the topic of study. The survey was used to find out the attitudes, opinions, or perceptions of the subject, especially about students' perception towards teaching vocabulary through the TPR method in school. A 4 point Likert scale ranging from 1 = strongly disagree; 2 = disagree; 3 = agree; $4=$ strongly agree was utilized to indicate responses in these statement items. The researchers delivered the questionnaire to the students after the TPR method was applied in the virtual classroom.

Second, a Focus Group Discussion (FGD) was conducted to follow up on the results of the online survey. The FGD aimed to reveal learning activities by means of the TPR method in the virtual classroom experienced by the participants. The FGD was administered virtually by helped the Thai teacher to translate the interview questions. However, the authors guarantee that it did not reduce the efficacy and quality of the discussion. (David Wilkson \& Peter Brimingham, 2003) state that FGD is a data collection technique that provides rich results and in-depth understanding because the participants can freely interact with each other to deal with the same topic of discussion at the same time. Some questions, i.e. "Do you can understand lessons quickly by using the TPR method virtually? Why?" and "Do you can learn English vocabulary faster by using the TPR method virtually? Why"

Table 1 Items of Survey

\begin{tabular}{cl}
\hline Survey items & \multicolumn{1}{c}{ Question } \\
\hline S1 & I feel easy learning with TPR method in virtual classroom \\
S2 & I feel enjoy and active learning with this method virtually \\
S3 & I love learning by using TPR method virtually \\
S4 & I feel happy to learn English through this method \\
S5 & I am motivated to learn English vocabulary through this method \\
S6 & I am able to learn the material through this method virtually \\
S7 & I get new information through this method \\
S8 & I can get more information using this method \\
S9 & I can learn the English vocabulary quickly and easily \\
S10 & I understand lessons quickly using this technique \\
\hline
\end{tabular}

\section{Data Collection}

The online survey was delivered to the students virtually. The questionnaire consists of 10 items and one sheet questionnaire for each student. After the data of the online survey were collected, the researchers did the Focus Group Discussion (FGD) with representative students to follow up on the results of the online survey. The participants were chosen randomly to participate in the FGD. In the FGD session, there are five (5) participants were in and shared their perception in teaching English vocabulary by using the TPR method virtually.

\section{Data Analysis}

The data obtained from the online survey and FGD were analyzed by following some procedures. First, the survey results were calculated in the form of percentages by using an Excel program. The percentage was used to indicate the students' perception toward teaching English vocabulary by applying the TPR method in a virtual class. The Likert scale was computed by finding out the total score per item using the formulation $\mathrm{T} x \mathrm{Pn}$, in which $\mathrm{T}$ is the total of responses and $\mathrm{Pn}$ is the Likert score (Halimah et al., 2018). The maximum score was 159, obtained from the maximal Likert score (4) x number of participants (39). Moreover, the authors determined the index (the percentage) by dividing the total score with the maximum score then was calculated by 100 . Lastly, the index was used as qualification criteria to draw the conclusion that was summarized as follows: $0-25 \%=$ strongly disagree, $26-50 \%=$ disagree, $51-75 \%=$ agree, and 76-100\% = strongly agree.

Second, the data from the Focus Group Discussion (FGD) were primarily arranged and identified based on the answers to the questions. The researchers read the transcription several times to get the initial points of students' 
perception in teaching English vocabulary by using the TPR method virtually. During the process, the researchers focused on the main information and removed unnecessary information. Finally, the excerpts which were relevant to the study were reported in the finding section. To ensure validity, the two authors reviewed and analyzed the data obtained from the FGD independently, and continued by stages of discussion to achieve the consensus of the final results.

\section{Result and Discussion \\ Result}

The result of students' perception in teaching English vocabulary through the TPR method virtually was shown in Table 2. In general, all the students positively perceived the implementation of the TPR method in learning English vocabulary in the virtual classroom. As shared by the students in the online survey, learning English vocabulary by means of the TPR method not only encouraged their learning interested and motivation but could also impact aspects of language that is vocabulary mastery.

Table 2 Students perception

\begin{tabular}{|c|c|c|c|c|c|c|c|}
\hline \multirow{2}{*}{ Items } & \multicolumn{4}{|c|}{ Responses } & \multirow{2}{*}{ Total } & \multirow{2}{*}{ Index } & \multirow{2}{*}{ Criteria } \\
\hline & SD & D & $\mathbf{A}$ & SA & & & \\
\hline S1 & 1 & 4 & 60 & 64 & 129 & $81.13 \%$ & Strongly Agree \\
\hline S2 & 2 & 14 & 42 & 64 & 122 & $76.72 \%$ & Strongly Agree \\
\hline S3 & 2 & 14 & 51 & 52 & 119 & $74.84 \%$ & Agree \\
\hline S4 & 4 & 8 & 63 & 40 & 115 & $72.32 \%$ & Agree \\
\hline S5 & 1 & 10 & 39 & 80 & 130 & $81.76 \%$ & Strongly Agree \\
\hline S6 & 1 & 8 & 66 & 48 & 123 & $77.35 \%$ & Strongly Agree \\
\hline S7 & 2 & 6 & 60 & 56 & 124 & $77.98 \%$ & Strongly Agree \\
\hline S8 & 3 & 2 & 54 & 68 & 127 & $79.87 \%$ & Strongly Agree \\
\hline S9 & 3 & 10 & 45 & 64 & 122 & $76.72 \%$ & Strongly Agree \\
\hline S10 & 3 & 8 & 57 & 52 & 120 & $75.47 \%$ & Agree \\
\hline Notes: & & $\begin{array}{l}\text { Stat } \\
\text { A } \\
\text { A }\end{array}$ & $\begin{array}{l}\mathrm{nt} \\
\mathrm{Str} \\
\mathrm{Ag}\end{array}$ & $\mathrm{Ag}$ & SD & $\begin{array}{l}\text { agree } \\
\text { ongly dis }\end{array}$ & \\
\hline
\end{tabular}

As showed in Table 2, mostly the results of the online survey in each statement were strongly agreed upon by the students. The statement number 1, the students were strongly agreed that they feel easy learning English vocabulary with this method virtually. It was indicated by the data from Table 2 , in which the index for statements number 1 was $81.13 \%$. For statement number 2, most of the students feel enjoy and active learning with this method virtually. It is seen that the index for the statement was $76.72 \%$ that means the students strongly agreed with statement number 2. Although, statements number 3 and 4 which are "the students love to learn English virtually through the TPR method", and "the students feel happy while teaching English vocabulary virtually." The indexes for the two statements were $72.32 \%$ and $74.84 \%$ that means the students agreed with those statements. In addition, the index of statement number 5 was $81.76 \%$ it means the students strongly agreed that the TPR method motivated them to be more active when learning English vocabulary virtually.

The result of the online survey in statement number 6 indicates that students are able to learn the material through this method virtually. The index for the statements was $77.35 \%$ it means the students agreed that they are able to learn the English vocabulary through this method virtually. Moreover, the students responded positively toward the TPR method virtually in teaching English vocabulary given the students new and more information. The indexes for the two statements were $77.98 \%$ and $79.87 \%$ it means the students strongly agreed that they get new and more information using this method. In addition, statement number 9 was also responded positively by the students. The index for that statement was $76.72 \%$ it means that the students strongly agreed that they can learn English vocabulary quickly and easily. The last statement of the survey is statement number 10. The students were agreed that learning English vocabulary using the TPR method virtually made them understood the lesson quickly and the index for that statement was $75.47 \%$. 
Moreover, the data obtained from the Focus Group Discussion (FGD) further supported the results of the online survey. In the FGD, the participants answer the questions to take in-depth information for this study. The researchers conducted the FGD with 5 students which chosen randomly. For the question in the interview itself, it consisted of 2 questions related to their perceptions toward the teaching English vocabulary through the TPR method virtually. The first question, "Do you can understand lessons quickly by using the TPR method virtually? Why?" and the second question "Do you can learn English vocabulary faster by using the TPR method virtually? Why?"

As a result of the FGD, The students have different opinions about the learning by this method virtually that concluded into 3 points. First, Most of the students argued that they can understand quickly through the TPR method virtually because in this method there are fun activities like the Simon says, listen and draw, listen and show, listen and do and etc., that make the students understand the lesson easier and they have felt the environment like in an offline classroom. Second, the students stated that they can learn vocabulary faster because the teacher gives direct instruction in memorable activities that make them easier to remember the words. Third, some of the students told that they cannot understand the lesson well in this virtual class. Because sometimes the unstable signal makes the students cannot hear the teachers' voice clearly. But, they were still happy with the fun activities in this virtual class.

\section{Discussion}

The present study aimed to investigate the students' perception toward teaching English vocabulary by applying the TPR method in a virtual classroom. The result of this study showed that almost all students positively responded that the virtual TPR method in teaching English vocabulary makes them feel easy, happy, and enjoy learning in the virtual classroom. They are able to learn the material through this method virtually because the TPR method is an easier technique to encourage students' motivation to more active during learning English vocabulary virtually. In addition, they can get new and more information during the activities included in the TPR method in the virtual classroom. Based on the result there are several main points that contribute to the students' perception in teaching English vocabulary toward the TPR method in the virtual classroom.

First, Most of the students argued that they can understand quickly through the TPR method virtually because in this method there are fun activities like the Simon says, listen and draw, listen and show, listen and do and etc., that make the students understand the lesson easier and they have felt the environment like in an offline classroom. The virtual classroom is not so different than the offline classroom (Alhat, 2020). However, in virtual classes, there are limitations in selecting activities in the TPR method that can be used. For example, by using commands or instructions and sing together so students can respond to them and can actively participate in activities in the virtual classroom. Therefore, the teachers can give some instructions to do the TPR activities during teaching English vocabulary. Based on (Savic, 2016) the most usual TPR activities involve the teacher's commands to which students respond physically, demonstrating comprehension. Some commands (Point to / Touch / Pick up (an apple / a pear / an orange / a strawberry) require using large motor skills, while others involve interaction with classroom objects. In addition, during virtual class, the classroom object can be changed with other things in their places and it will not decrease the quality of that activity.

In addition, the benefits of using the TPR method in teaching a foreign language to children were body movement (large-motor skills) can strengthen language learning and have the potential to strengthen children's physical development; enjoyment created in stress-free activities that focus on physical movement can further increase children's involvement, increase motivation to participate in action games, and make foreign language learning truly effective. The general objective of the TPR teaching method is to make the students learn to use the language. The initial stage of teaching is to let the students understand the content of the study and to teach the language through action.

Second, the students stated that they can learn vocabulary faster because the teacher gives direct instruction in memorable activities that make them easier to remember the words.

The TPR teaching method is based on simple instructions. The main teaching method in the TPR is the "listenact model" which involves a lot of bodily movements. The instruction in this way is to express an understanding of strong memory and can improve the students' memorization skills (Shi, 2018). According to (Bahtiar, 2017) the use of TPR is like the learning process becomes more fun, students easily to memorize the vocabulary, all students were actively involved in the learning process, and both students and teachers are happy in the teaching and learning process. In addition, the TPR teaching method can arouse students' interest in learning English. The TPR method is an effective method to improve students' vocabulary mastery (Khakim \& Anwar, 2020; Gayanti \& Satriani, 2020). 
Furthermore, there are some students who cannot understand the lesson well in this virtual class. They stated that because the unstable signal makes the students cannot hear the teachers' voice clearly. One of the main disadvantages is that it requires a computer and a steady internet connection (Alhat, 2020). However, all of that can be resolved with activities that have been carried out during the learning process. They were still happy to learn English vocabulary by applying fun activities from the TPR method in the virtual classroom.

\section{Conclusion}

Drawing on the result and discussion, the present study reveals that the majority of students positively responded that the TPR method can be applied in teaching English vocabulary in the virtual classrooms. Virtual classrooms are online environments that allow students and teachers to communicate simultaneously using audio, video, text chat, interactive whiteboards, app sharing, instant polls, and more. This feature allows teachers and students to interact as if they were face to face in class. Participants can talk to each other, see each other via webcam, use emoticons, and work together in the break room (Parker \& Martin, 2010). Mostly, the students interested to learn English vocabulary in the virtual class during the new normal era using TPR method virtually. That can be seen from the students feeling more enjoy, happy, and active to learn English vocabulary by TPR method during the virtual classroom. They also show that learning English vocabulary in the virtual classroom is not a difficult thing by following the variation of activities and interaction in the TPR method virtually. It could help the students to understand and remember new vocabulary very well.

\section{Reference}

Alhat, S. (2020). Virtual Classroom: A Future of Education Post-COVID-19. Shanlax International Journal of Education, 8(4), 101-104. https://doi.org/10.34293/education.v8i4.3238

Bahtiar, Y. (2017). USING THE TOTAL PHYSICAL RESPONSE TO IMPROVE STUDENTS' VOCABULARY MASTERY. SELL Journal, 2(1), 9-23.

Cameron, L. (2010). Teaching Languages to Young Learners. In Cambridge University Press. Cambridge University Press. https://doi.org/10.1017/cbo9780511733109.002

David Wilkson \& Peter Brimingham. (2003). Using Research Instrument: A guide for researchers. Psychology Press.

Eka, E., \& Setiawan, J. E. (2018). Teaching English Vocabulary Using Tpr (Total Phyisical Response) Method At the Fifth Grade Students of Sdn Cinerang Cianjur in Academic Year of 2017/2018. PROJECT (Professional Journal of English Education), 1(5), 696-702.

Fahrurrozi. (2017). Improving Students 'Vocabulary Mastery by Using Total Physical Response. Canadian Center of Science and Education, 10(3), 118-127. https://doi.org/10.5539/elt.v10n3p118

Gayanti, R., \& Satriani, I. (2020). Teaching Students' Vocabulary Through Total Physical Response. PROJECT (Professional Journal of English Education), 3(3), 414. https://doi.org/10.22460/project.v3i3.p414-419

Halimah, H., Lustyantie, N., \& Ibrahim, G. A. (2018). Students' Perception on the Implementation of Orai Application in Cll Method in Teaching Speaking. JEELS (Journal of English Education and Linguistics Studies), 5(1), 1-22. https://doi.org/10.30762/jeels.v5i1.566

Ho, P., Thi, N., Anh, C., Vu, P., \& Ho, P. (2018). the Effect of Using Total Physical Response (Tpr) on Efl Young Learners' Vocabulary and Speaking Fluency Kỷ Yếu Hội Thảo Khoa Họ 128 the Effect of Using Total Physical Response (Tpr) on Efl Young Learners' Vocabulary and Speaking Fluency. September. https://www.researchgate.net/publication/327835425

Ibrohim, A. T., \& Septianti, A. (2018). STUDENTS' PERCEPTION TOWARD TEACHING ENGLISH VOCABULARY THROUGH TOTAL PHYSICAL RESPONSE ( TPR ) METHOD. PROJECT (Professional Journal of English Education), 1(2), 145-156. https://doi.org/http://dx.doi.org/10.22460/project.v1i2.p145-156

Khakim, L., \& Anwar, C. (2020). Improving Students' Vocabulary Mastery Through Total Physical Response Learning Method. Advances in Social Science, Education and Humanities Research, 409(SoRes 2019), 506-512. https://doi.org/10.2991/assehr.k.200225.110

McMillan, James H., and S. S. (2001). "Research in Education: A Conceptual Introduction. Wesley Longman.

Parker, M. A., \& Martin, F. (2010). Using Virtual Classrooms : Student Perceptions of Features and Characteristics in an Online and a Blended Course. 6(1), 135-147.

Shi, T. (2018). A Study of the TPR Method in the Teaching of English to Primary School Students. Theory and Practice in Language Studies, 8(8), 1087-1093. https://doi.org/http://dx.doi.org/10.17507/tpls.0808.25

Widodo, H. P. (2005). Teaching Children Using a Total Physical Response ( TPR ) Method : Rethinking. 
Journal of English Teaching, Literature, and Applied Linguistics ISSN 2202-9478

Vol. 5, No. 1; February 2021

Published by English Language Education Department of UMG

Bahasa Dan Seni, 33(2), 235-248. 